\title{
Acute Hepatitis E. virus infection in Egypt
}

\author{
Osman $^{*}$, F, Abu-Shady ${ }^{* *}$, EA, Abd El-Wahab ${ }^{* *}$, KSE, El-Rashidy ${ }^{* *}$, ZE, \\ Abbassia Fever Hospital, Ministry of Public Health* \\ Microbiology Department, Faculty of Medicine- \\ Al-Azhar University (Girls)**
}

\begin{abstract}
Hepatitis E virus (HEV) is largely responsible for water borne epidemics in many developing countries. The principle mode of HEV transmission is the fecal oral route in epidemic and sporadic forms with a high case fatality ratio in pregnant women. Serum samples from 50 healthy subjects and from 435 acute viral hepatitis patients, 4-75 years old, were screened for markers of acute viral hepatitis. These included $\left(\mathrm{HB}_{\mathrm{s}} \mathrm{Ag}\right.$, anti- $\mathrm{HBc}(\mathrm{IgM})$, antiHDV (IgM), HAV (IgM), anti-HCV (IgG), and anti-HEV (IgG), and (IgM) tests by enzymelinked immunoassays (EIA).

Furthermore isolation of HEV from peripheral blood lymphocytes and from stools belonging to anti-HEV IgG-positive patients was attempted by inoculation of $\mathrm{HepG}_{2}$ and Vero cell line cultures. The inoculated cell cultures were examined after immunoperoxidase staining for the detection of HEV antigen. Plasma, lymphocytes and stool samples from anti-HEV IgM positive patients were examined for HEV RNA by PCR.

Anti-HEV IgG was found in 144/435 (33\%) of these acute hepatitis patients. Anti-HEV (IgM) was detected in $8 / 52(15.4 \%)$ out of 52 chosen from the 144 sera that were anti-HEV IgG positive cases.

$\mathrm{HEV}$ was isolated in $\mathrm{HepG}_{2}$ from $32.6 \%$ of lymphocyte and from $34.9 \%$ of stools from patients positive for anti-HEV (IgG). While it was isolated from $71.4 \%$ of lymphocytes and from $100 \%$ of stools from patients positive for anti-HEV (IgM). In Vero cell cultures there was no HEV isolation from stools but HEV was isolated from 50\% of lymphocytes. HEV RNA was detected by PCR in $85.7 \%$ of stools, $62.5 \%$ of plasma, and in $37.5 \%$ of lymphocyte samples belonging to anti-HEV IgM positive cases. Analysis of these diagnostic tests indicated that virus isolation from peripheral blood lymphocytes and stools by inoculation of $\mathrm{HepG}_{2}$ cell cultures is more sensitive than virus-RNA detection by PCR
\end{abstract}

\section{Introduction}

Hepatitis E virus (HEV) causes an enterically transmitted hepatotropic infection spreads by the fecal oral route usually through fecally polluted water. Acute viral hepatitis develops after an incubation period of 8-10 weeks. Clinical attack rates are the highest among young adults. Asymptomatic and anicteric infections occur but chronic HEV infection is not recorded. Acute HEV hepatitis may be particularly severe among pregnant women, with maternal mortality rates reaching as high as $25 \%$ as opposed to $0.07-0.6 \%$ in the general population (Mishra and Seef, 1992). Abortion with evidence of fetal HEV infection followed acute maternal infection (Abdel Wahab et al. (1996); Abou El Kheir et al. (2004) under publication).

In humans and in experimental virus infection of animals viral excretion in stools began approximately 1 week prior to the onset of illness and persisted for nearly 2 
weeks, while viremia was detected late in the incubation period and during acute hepatitis by amplifying virus RNA by a polymerase chain reaction (PCR).

Immunoglobulin $\mathrm{M}$ antibody specific to HEV (anti-HEV) inconsistently appears early during clinical illness but disappears rapidly over a few months. (Bryan et al., 1994). Immunoglobulin G anti HEV appears a few days later than IgM and persists for at least a few years (Khuroo et al., 1993).

Our aim in the present study is to assess the best diagnostic criterion of HEV infection in Egyptian hepatitis patients.

\section{Materials and Methods}

\section{Subjects}

Four hundred and thirty five (435) acute hepatitis patients, 285 males and 150 females from 4 to 75 years old were admitted to Abbassia fever Hospital between July 1997 and July 1998. All patients had febrile jaundice. Fifty healthy adults were recruited as control group.

\section{Samples}

From all the patients and controls about $10 \mathrm{ml}$ blood sample was taken in two tubes one with anti-coagulant and the other without anti-coagulant. Stools samples were also taken and stored at $-30^{\circ} \mathrm{C}$ until the samples were processed for virus isolation and for PCR.

\section{Methods}

Serum samples of all patients and controls were tested for liver enzyme function and for detection of the following viral hepatitis markers by commercial EIA kits (ABBOTT) which included anti-HAV $(\operatorname{IgM}), \mathrm{HB}_{\mathrm{s}} \mathrm{Ag}$, anti-HB $\mathrm{HB}_{\mathrm{c}}(\mathrm{IgM})$, anti-HDV (IgG) for $\mathrm{HB}_{\mathrm{s}} \mathrm{Ag}$ positive samples, antiHCV (IgG), and anti-HEV (IgG). AntiHEV (IgM) were tested by a modification of the anti-HEV (IgG) kit (El-Zimaity et al., 1993).
Stools were prepared for viral RNA extraction according to Chomcyznski and Sacchi (1987) method. Peripheral blood lymphocytes (p.bl.ly.) were separated by ficol-hypaque density gradient centrifugation. When sera were positive for antiHEV (IgG) further investigation was carried out for virus isolation by inoculation of correspondent p.bl.ly. and stools extracts into cultures of Vero and of $\mathrm{HepG}_{2}$ cell lines. Because HEV did not produce cytopathic effects (CPE) in $\mathrm{HepG}_{2}$ or Vero cells further tests were done for detection of intracellular HEV antigens by an indirect immunoperoxidase staining.

Also the relevant plasma, (p.bl.ly.) and stools extracts from patients who had anti-HEV IgG were tested for the presence of HEV RNA by polymerase chain reaction (PCR). (Turkoglu, et al, 1996).

\section{Results}

\section{Clinical Picture}

All patients had jaundice, fever and tender right hypochondrium. Hepatomegaly was found in $(31 \%)$ of the patients and spleenomegaly in $(7.7 \%)$. One male patient had ascitis. Liver enzyme functions were 2.5 to 5 times the normal for Egyptians. Bilirubin was elevated up to $26 \mathrm{mg} / \mathrm{dl}$ in some cases. One female 20 years old patient who was 4 months pregnant had an abortion 6 hours earlier to hospital admission. She was comatosed. Her admission laboratory findings were: bilirubin 10.5 $\mathrm{mg} / \mathrm{dl}$, AST 208, and ALT 180 she had mild degree anaemia and her serum sample was anti-HEV IgG positive and anti-HEV $1 \mathrm{gM}$ negative by EIA. She recovered without further complication.

\section{Serological Markers of Hepatitis Viruses}

Table (1) shows the serological markers basis for diagnosis. Acute hepatitis $\mathrm{B}$ was diagnosed in $16 \%$ of cases, acute hepatitis $\mathrm{A}$ in $11 \%$ of cases, hepatitis $\mathrm{C}$ in $31 \%$ of cases, IgG anti hepatitis $\mathrm{E}$ in $33 \%$ of cases, and IgM anti HEV in 8/52 (55\%) none A, B, C, E in $15 \%$ of cases. While co- 


\section{Osman et al}

infection with more than one hepatitis virus was detected in $9 \%$ of cases and HBV coinfection with $\mathrm{HDV}$ in $8 \%$. There was HBsAg alone in $3 \%$ was possible chronic carrier state or early HBV infection.

For comparison, a serological marker of non-ceitric non-febrile $\mathrm{HBV}$ infection possible chronic carriage of $\mathrm{HBsAg}$ was detected in $1 / 50(2 \%)$. Anti-HCV igG was detected in $3 / 50(6 \%)$ of the sera from control subjects (Table 2) which represents non-symptomatizing chronic $\mathrm{HCV}$ infection in the population.

\section{Co-infection with Hepatitis Viruses}

In this study 39 out of 435 serum samples were positive for markers of more than one hepatitis virus, the most frequent of these co-infections was 20/39 (51.3\%) IgG anti$\mathrm{HCV}$ and IgG anti-HEV (Table 3):

\section{Age Related Frequency of Hepatitis Virus Infection}

Our results (Table 4) show that acute hepatitis B virus affected mainly young adults [21-30 years 24/70 (34\%)] while hepatitis A virus affected mainly children [0-10 year, 25/48 (52\%)]. But an acute HAV infection at 11-30 years of age [23/ 48(47.9\%)] reflects a change of herd immunity to HAV. Anti-HCV IgG positive patients were spread over the ages with a maximum mainly in age group (41-50 years) 66 / $135(48 \%)$ suggesting existence of a risk factor(s) for HCV infection 40-60 years ago.

HEV infected young adults [(21-30 years). 54/144 (37.5\%)] more than other groups, yet HEV infection is spread over age groups up to 61-70 years. This may be explained by re-infections due to shortlived immunity to a single serotype or reinfection with serogroups that do not share cross-protection (Table 4).

\section{Hepatitis $\mathbf{E}$ virus isolation in $\mathbf{H e p G}_{2}$ cell cultures}

HEV was isolated in $\mathrm{HepG}_{2}$ cell culture from 15/46 (32.6\%) p.bl.ly. and from 15/43 (34.9\%) stools of anti-HEV IgG and IgM positive patients. (Fig. 1, and Fig. 2a, 2b). HEV was isolated from 10/39 $(25.6 \%)$ p.bl.ly. and from 8/36 (22.2\%) stools of anti-HEV IgG positive patients. HEV was isolated from 5/7 (71.4\%) p.bl.ly. and from $7 / 7$ (100\%) stools of anti-HEV IgM positive patients. Thus, virus isolation in $\mathrm{HepG}_{2}$ is an efficient diagnostic test.

\section{Hepatitis E virus isolation in Vero cell cultures}

HEV was isolated from $4 / 8(50 \%)$ p.bl.ly. samples but not from stools samples though the patients were anti-HEV IgM positive (Fig. 3a, 3b).

\section{Comparison of diagnostic tests for HEV infection}

Fig (4) shows that PCR test detected HEV-RNA more in plasma samples than in stools, or in p.bl.ly. in that order Using PCR HEV RNA was detected in5/8 (62.5\%) plasma samples, in 3/8 (37.5\%) p.bl.ly. samples and in 6/7 (85.7\%) stool samples (patients were anti-HEV IgM positive). Thus when the patient is IgM anti HEV positive the best diagnostic test is $\mathrm{HEV}$ isolation in $\mathrm{HepG}_{2}$ cell cultures using stools and p.bl.ly. PCR ranked second to virus isolation in $\mathrm{HepG}_{2}$ in this situation. When the patient was IgM plus IgG anti HEV positive the chances of HEV isolation is $\mathrm{HepG}_{2}$ is equal whether PBL or stools is used while PCR does not offer an advantage in HEV diagnosis. Using cell culture HEV was isolated from 15/46 $(32.6 \%)$ p.bl.ly. samples and from 15/43 $(34.9 \%)$ stools samples cultured in $\mathrm{HepG}_{2}$ cell line (all patients were anti-HEV IgG positive), and from 5/7 (71.4\%) p.bl.ly. and from $7 / 7$ (100\%) stools when patients were anti HEV IgM positive. Using VERO cell line HEV was isolated from 4/8 (50\%) p.bl.ly. samples and could not be isolated from any stool samples (all patients were anti-HEV IgM positive). Using EIA antiHEV IgM was detected in $8 / 52(15.4 \%)$ serum samples positive for anti-HEV IgG. 
Table (1): Acute Clinical Hepatitis: Serological Markers of Hepatitis Viruses

\begin{tabular}{||l|l|l|l|l|}
\hline Hepatitis virus & Positive & Negative & Total & Percent \\
\hline HBsAg and anti-HBc IgM & 70 & 365 & 435 & $16 \%$ \\
\hline Anti-HDV-Ag +HBsAg & 7 & 76 & 83 & $8 \%$ \\
\hline HBsAg & 13 & 422 & 435 & $3 \%$ \\
\hline Anti-HAV IgM & 48 & 387 & 435 & $11 \%$ \\
\hline Anti-HCV IgG & 135 & 300 & 435 & $31 \%$ \\
\hline Anti-HEV IgG & 144 & 291 & 435 & $33 \%$ \\
\hline Anti-HEV IgM & 8 & 44 & 52 & $15.4 \%$ \\
\hline Non A-E & 66 & -- & 435 & $15 \%$ \\
\hline $\begin{array}{l}\text { Multiple markers of hepatitis } \\
\text { viruses }\end{array}$ & 39 & 396 & 435 & $9 \%$ \\
\hline
\end{tabular}

Table (2): Control group: Markers of hepatitis viruses

\begin{tabular}{|l|l|l|l|l|}
\hline \hline Hepatitis virus & Positive & Negative & Total & Percent \\
\hline HBsAg & 1 & 49 & 50 & $2 \%$ \\
\hline Anti-HBc IgG & 0 & 50 & 50 & $0 \%$ \\
\hline Anti-HAV IgM & 0 & 50 & 50 & $0 \%$ \\
\hline Anti-HCV IgG & 3 & 47 & 50 & $6 \%$ \\
\hline Anti-HAV IgM & 0 & 50 & 50 & $0 \%$ \\
\hline
\end{tabular}

Table (3): Markers Of Hepatitis Viruses Co-Infection inEgyptian Hepatitis Patients

\begin{tabular}{|l|l|l|}
\hline $\begin{array}{l}\text { Markers of co-infection with hepatitis viruses } \\
\text { in 39 out of 435 patients }\end{array}$ & Sera & Percent \\
\hline Anti-HCV and anti-HEV IgG & 20 & $51.3 \%$ \\
\hline $\mathrm{HBs}$ Ag and anti-HEV IgG & 5 & $12.8 \%$ \\
\hline HBs Ag, anti-HCV IgG and anti-HEV IgG & 2 & $5.1 \%$ \\
\hline HBs Ag, anti-HBc IgG and anti-HEV IgG & 1 & $2.6 \%$ \\
\hline Anti-HBc IgM and anti-HEV IgG & 1 & $2.6 \%$ \\
\hline Anti-HAV IgM and anti-HEV IgG & 2 & $5.1 \%$ \\
\hline HBsAg and anti-HBc IgM and anti-HCV IgG & 1 & $2.6 \%$ \\
\hline Anti-HBc IgM and anti-HCV IgG & 1 & $2.6 \%$ \\
\hline
\end{tabular}

Table (4): Distribution of Hepatitis Viruses Markers in Relation to Hepatitis Patient Age

\begin{tabular}{|l|c|c|c|c|c|c|c|c|}
\hline $\begin{array}{l}\text { Positive hepatitis } \\
\text { marker }\end{array}$ & $\mathbf{0 : 1 0 Y}$ & $\mathbf{1 1 :} 20 \mathrm{Y}$ & $\mathbf{2 1 : 3 0 Y}$ & $\mathbf{3 1 :} \mathbf{4 0 Y}$ & $\mathbf{4 1 : 5 0 Y}$ & $\mathbf{5 1 : 6 0 Y}$ & $\mathbf{6 1 : 7 0 Y}$ & Total \\
\hline $\begin{array}{l}\text { HBsAg and } \\
\text { anti-HBc IgM }\end{array}$ & 5 & 16 & $\mathbf{2 4}$ & 11 & 9 & 3 & 2 & 70 \\
\hline HB sg $_{\text {Ag }}$ & 1 & 3 & 4 & 3 & 1 & 1 & -- & 13 \\
\hline Anti-HAV IgM & $\mathbf{2 5}$ & 15 & 8 & -- & -- & -- & -- & 48 \\
\hline Anti-HCV IgG & -- & 2 & 16 & 25 & $\mathbf{6 6}$ & 21 & 5 & 135 \\
\hline Anti-HEV IgG & 3 & 33 & $\mathbf{5 4}$ & 18 & 18 & 12 & 6 & 144 \\
\hline
\end{tabular}




\section{Osman et al}

Fig. (1) HEV Isolation from Stools and Peripheral Blood Lymphocytes in Hepg 2 Cell Culture: Correlation with Anti-HEV IgG and/or IgM Reactive Sera.

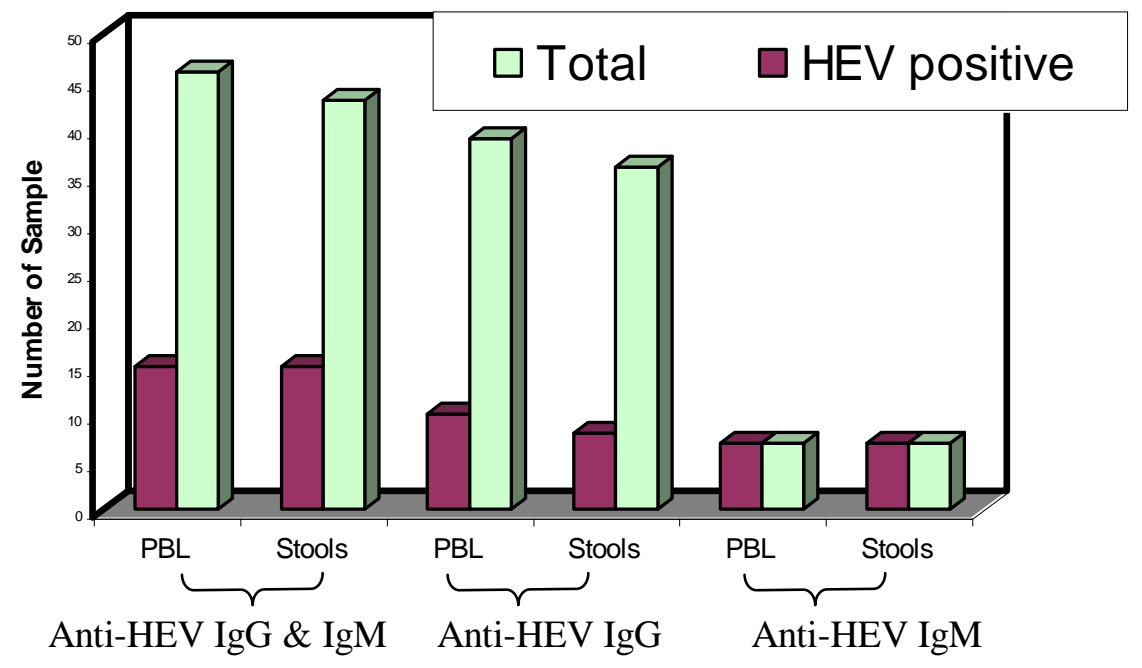

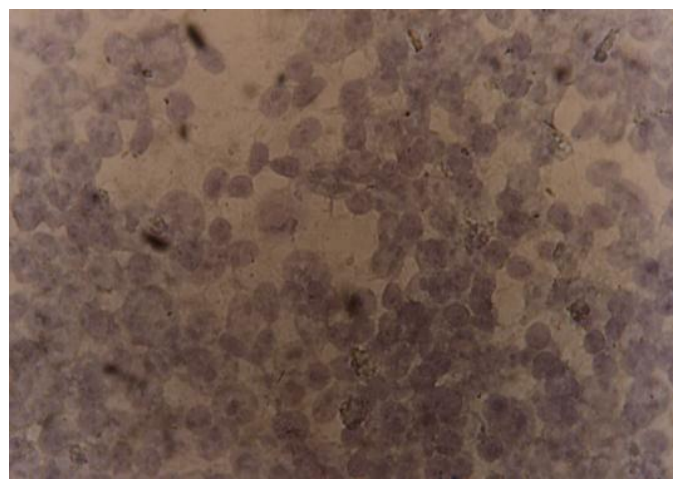

Fig. (2a): $\mathrm{HepG}_{2}$ cell culture negative for HEV antigen by indirect immunoper-oxidase. (40 x 10).

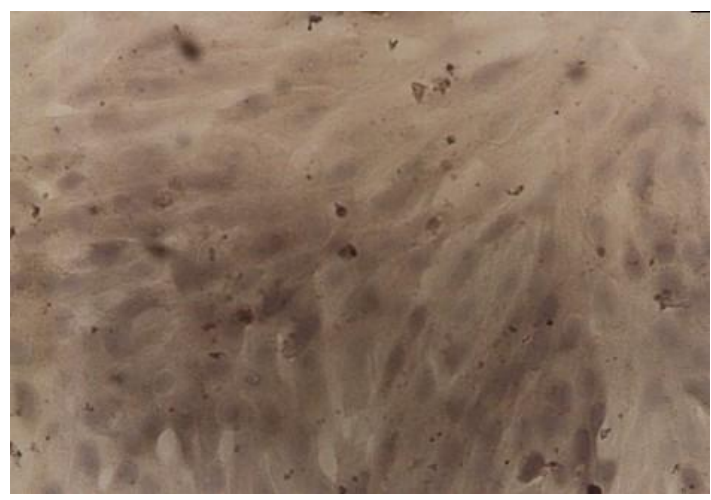

Fig. (3a): Control VERO cell culture negative for HEV antigen stained by

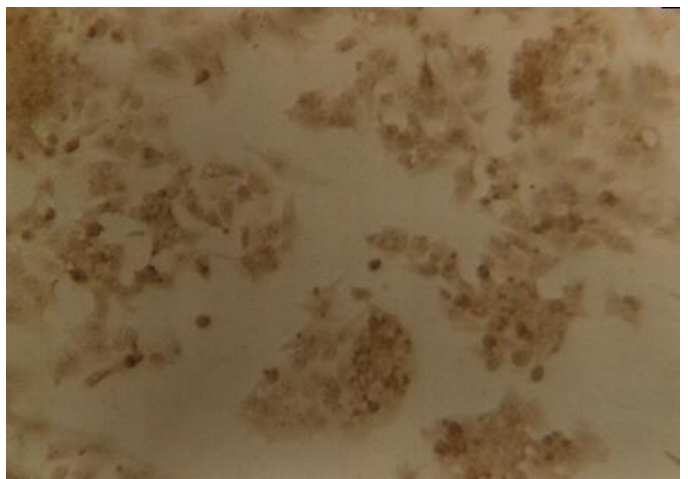

Fig. (2b): $\mathrm{HepG}_{2}$ cell culture stained by indirect immunoperoxidase. The dark brown positive reaction for HEV antigen is located both in cytoplasm and in nuclei $(25 \times 10)$.

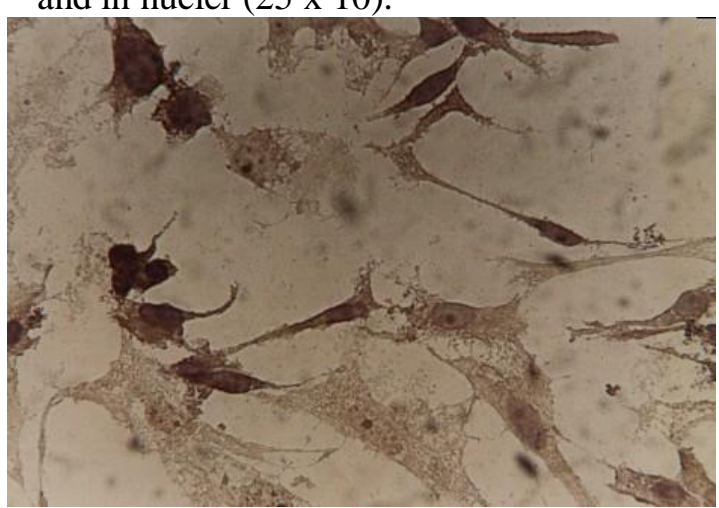

Fig. (3b): VERO cell culture showing dark brown positive reaction of $\mathrm{HEV}$ 
indirect immunoperoxidse staining (25 x 10). antigen located in both cytoplasm and nuclei $(40 \times 10)$.

Fig. (4): Clinical hepatitis: Diagnostic Profile of anti-HEV IgM Positive Patients.

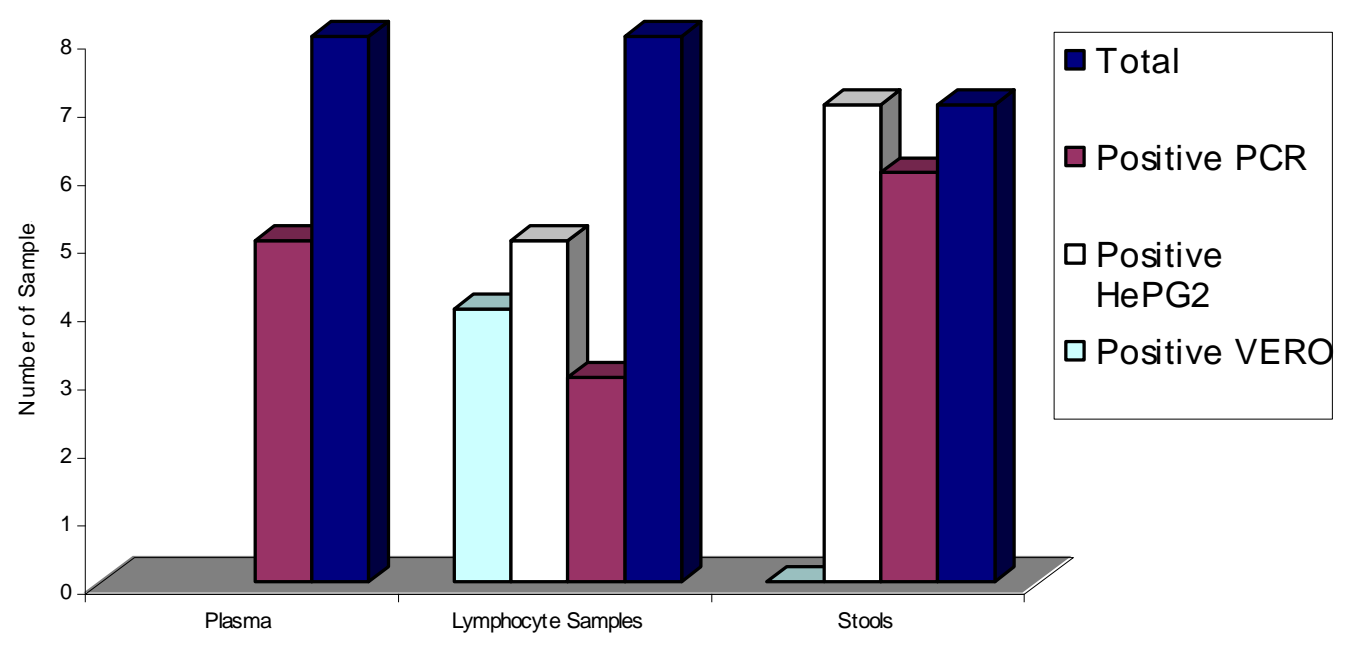

\section{Discussion}

In the present study anti-HEV IgG was detected in 144 out of 435 (33\%) of sporadic hospitalized hepatitis patients. These results reinforce previous studies, which indicated that HEV is a common cause of acute sporadic childhood hepatitis in Egypt. [Goldsmith et al. (1992), ElZimaity et al. (1993), Kamel et al. (1994), Gomatos et al. (1996) Abdel Wahab et al. (1996), and Divizia et al. (1999)] as well as adulthood hepatitis (Abdel Wahab et al. (1996) and Abo El kair et al. 2004 (under publication).

Because the appearance of IgM antiHEV immune response is not predictable EIA was used for detection of anti-HEV IgM in the sera of (52) anti-HEV IgG positive cases. Only $8 / 52(15.4 \%)$ were found to be positive for anti-HEV IgM (Table 1) which were considered as acute HEV infection. Stools and lymphocytes of these (8) cases were inoculated in $\mathrm{HepG}_{2}$ and in VERO cell lines for HEV isolation and for detection of HEV antigens by immunoperoxidase staining.

The question whether IgM antibody heralds clearance of HEV viraemia was raised. Therefore, sera, Lymphocytes and stools of these (8) cases were examined by PCR test to detect the presence of HEV RNA. HEV RNA was detected in $5 / 8$ $(62.5 \%)$ of sera, in $3 / 8 \quad(37.5 \%)$ of lymphocytes and in 6/7 (85.74\%) of stools (Fig. 3 \& 4). Although the number of samples tested is small, yet, it is clear that there is ongoing viraemia and virus excretion in stools. This is in agreement of other studies which detected HEV RNA in many HEV hepatitis acute phase stools and sera by PCR (Ray et al., 1991), McCaustland et al. (1991), Turkoglu et al. (1996), Divizia et al. (1999), Bussion et al. (2000) and Aggarwall et al. (2000)). Our finding of low recovery of HEV-RNA from lymphocytes (Fig. 4) distinguishes it from other enteroviruses.

An overall investigation for serological markers of other hepatotropic viruses (HBV, HCV and HAV) infections by EIA technique revealed $\mathrm{HBsAg}$ in $5 / 52$ $(9.6 \%)$ and anti-HBc (IgM) in (1/52) $(1.9 \%)$ of anti-HEV IgG positive cases which may indicate acute HBV infection on top of past infection of HEV. Likewise, anti-HCV IgG was detected in $14 / 52$ (26.9\%) of these anti-HEV IgG positive 


\section{Osman et al}

samples. These two results are indicators of the frequent exposure to hepatotropic viruses in Egypt. Meanwhile, there were $33 / 52(63.5 \%)$ sera positive for anti-HEV $\mathrm{IgG}$ alone. This was considered pure HEV infection. Detection of multiple re-activities to hepatitis viruses markers in a serum indicated that among Egyptian patients suffering from acute hepatitis there may be an ongoing one or more hepatotropic virus activity (Table 3 ). But there is a possibility of an induction of polyclonal anti-body reactivity related to $\mathrm{HCV}$ chronic infection. There were many trials to culture HEV (Kazachkov et al. (1992) Meng et al. (1996) Jameel et al. (1996) Dzagurov et al. (1997 Divizia et al. (1999) Huang et al. (1999) and Panda et al. (2000). In the current study inoculation of stools and of p.bl.ly. in $\mathrm{HepG}_{2}$ provided evidence that HEV replicated in these experimentally infected cells. Viral antigens were detected by an immuneoperoxidase staining in $15 / 43$ $(34.9 \%) \quad \mathrm{HepG}_{2}$ inoculated with stools samples and in 15/46 (32.6\%) $\mathrm{HepG}_{2}$ inoculated with lymphocytes from antiHEV IgG positive patients. Previously Jameel et al. (1996) and Panada et al (2000) results indicated that $\mathrm{HepG}_{2}$ supported $\mathrm{HEV}$ replication. As shown in our study: 5/7 (71.4\%) of $\mathrm{HEV}$ isolations were detected by immunostaining of $\mathrm{HepG}_{2}$ cells inoculated with lymphocytes, and $3 / 8$ $(37.5 \%)$ of these lymphocytes were positive for HEV RNA by PCR. So when lymphocytes of anti-HEV $1 \mathrm{gM}$ positive cases were used as a sample of choice, $\mathrm{HEV}$ inoculation in $\mathrm{HepG}_{2}$ cells gave a higher percentage of positive cases than HEV RNA detection by PCR. Vero cell cultures were less efficient than $\mathrm{HepG}_{2}$ for HEV propagation in our experience. Further work to improve Vero cell receptivity for HEV is needed.

The use of stools for HEV diagnosis in our experience was rewarding. Virus isolation by inoculation of $\mathrm{HepG}_{2}$ cells diagnosed 7/7 (100\%), while HEV RNA was detected in $6 / 7$ (85.7\%) using PCR. Failure to detect HEV-RNA in 1/7 stools sample may be related to a low virus load. Putting in consideration that by the time hepatitis patients in Egypt are hospitalized they are in the early convalescence phase. Therefore some re-considerations of the markers of virus diagnosis should be involved.

Our results suggest that stools are the sample of choice for the diagnosis of acute HEV infection. The most sensitive diagnostic test was HEV isolation in $\mathrm{HepG}_{2}$ cell line followed by immunoperoxidase staining of cytoplasmic HEV antigens and by HEV RNA detection by PCR. We would like to stress that $\mathrm{HEV}$ replication in $\mathrm{HepG}_{2}$ cells enhances viral antigen and or RNA concentration with improved viral diagnosis. Serological diagnosis alone did not document HEV etiology because while IgG anti HEV was detected in 44/435 (33\%) there were markers of $\mathrm{HBV}$ or $\mathrm{HAV}$ or $\mathrm{HCV}$ viruses. After etiologic shuffling there was only $33 / 435(7.58 \%)$ single $\operatorname{IgG}$ anti HEV marker and 8/435 (1.84\%) IgM anti HEV single marker. In our hands screening for IgG anti-HEV should be combined with $\mathrm{HepG}_{2}$ cell culture for virus isolation from stools. For fast diagnosis, though not highly sensitive PCR of stools is rewarding though costly to be done as routine.

\section{References}

1. Abdel Wahab KSE, Abushady E.A., ElMalah A. and Abd El Moneim A. (1996): Acute hepatitis $\mathrm{E}$ virus infection among Egyptian children. Hepatol, Gastroenterol Infect Dis. 4: 75-82.

2. Abdel Wahab KSE, Ismail AA, Abu Sady (1996): Hepatitis E virus infection (HEV) and its effect on pregnancy outcome among Egyptian women. J Egypt Soc Gyn and Obst. 22: 603-609.

3. Abo El Kair AAK, Abdel Wahab KSE, Ali MA, Abdel Kader, N, and Abdel Aziz (2004): Assessment of hepatitis $E$ and Parvo virus $\mathrm{B} / \mathrm{g}$ viral infections and its effects on Egyptian pregnant mothers under publication.

4. Aggarwal R., Kini Dinesh, Sofat Sunil, Naik S.R. and Krawczynski K. (2000): Duration of viraemia and faecal viral excretion in acute hepatitis E. Lancet 356: 1081-1082.

5. Bryan J.P., Tsarey S.A., Iqbal M., Ticehurust J., Emerson S. and Ahmed A. (1994): Epidemic hepatitis $E$ in Pakistan: patterns of serologic response and evidence 
that antibody to hepatitis E virus protects against disease J Infect Dis 170:517-521.

6. Buisson Y., Grandadam M., Nicand E., Cheval P., Van Cuyck-Gandre H., Innis B., Rehel P., Coursaget, P., Teyssou R. and Tsarev S. (2000): Identification of a novel hepatitis E virus in Nigeria. J Gen Virol 81: 903-909.

7. Chomczynski P. and Sacchi N. (1987): Single step method of RNA isolation by acid guanidium thiocyanate-phenyolchloroform extraction. Analy Biochem 162:156-159.

8. Divizia M., Gabrieli R., Stefanoni M.L., Renganathan E., El-Ghazzawi E., Kader O.A., Gamil F., El-Sawaf G., El-Sherbini E., Saleh E., Degener A.M., Noce A., Zaratti L., Modesti A and Pana A. (1999): HAV and HEV infection in hospitalized hepatitis patients in Alexandria, Egypt. Eur J Epidemiol 15: 603-609.

9. Dzagyurov G.K., Kuprijanov V.V., and Balaian M.S., (1997): Study of hepatitis E virus replication in FRhk-4 cell culture. Vopr Virusol 42: 63-66.

10. El-Zimaity, D.M., Hyams, K.C. Imam, I.Z. Watts, D.M., Bassily, S., Naffen, E.K. Sultan, Y. Emara, K., Burans, J. and Purdy, M.A. (1993): Acute sporadic hepatitis $\mathrm{E}$ in an Egyptian pediatric population. Am J Trop Hyg 48: 372-376.

11. Goldsmith R., Yarbough P.O., Reyes G.R. Fry K.E., Gabor K.A. Kamel M., Zakaria S., Amer. S., and Gaffar Y. (1992): Enzyme linked immunosorbent assay for diagnosis of acute sporadic hepatitis E in Egyptian children. Lancet 339:328-331.

12. Gomatos P.J., Mounir M.K., Arthur R.R., Rodier G.R. Gacknart B.G. Saad M.D. El-Zimaity D., Hyams K.C. Osman F., Nassef H.F., Quinti I., El-Sahly A.M., Emara K., Sultan Y. and Imam I.Z. (1996): The etiology of communityacquired viral hepatitis in Cairo, Egypt: Diagnosis of Hepatitis E Virus infections. Egyptian J Med Microbiol 5: 223-229.
13. Huang R., Li D., Wei, S., Li Q. Yuan X., Geng L., Li X. and Liu M. (1999): Cell culture of sporadic hepatitis $\mathrm{E}$ virus in China. Clin. Diag Lab Immunol 6: 729-733.

14. Jameel S., Zaafrulaah M. Ozdener M.H. and Panda S.K. (1996): Expression in animal cells and characterization of the hepatitis E virus structural proteins. J Virol 70: 207-216.

15. Kamel M., Troomen H., Ritter A., Pelzer C., Simpson B. and Miller F.D. (1994): HEV endemicity among Egyptian villagers J Hepatol 21: 191-198.

16. Kazachkov Y.A., Balayan M.S., Ivannikova T.A., Panina L.I., Orlova T.M., Zamyatina N.A. and Kusov Yu. Yu. (1992): Hepatitis E virus in cultivated cells. J Arch Virol 127:339-402.

17. Khuroo M.S., Kamili, S., Dar M.Y., Moecklii R. and Jameel S. (1993): Hepatitis E and long-term antibody status. Lancet 341:335.

18. McCaustland, K.A. Shengli B.I., Purdy M.A. and Bradley D.W. (1991): Application of 2 RNA extraction methods prior to amplification of Hepatitis E Virus nucleic acid by the polymerase chain reaction. J Virol Methods 35: 331-342.

19. Panda S.K., Ansari I.H., Durgapal H., Agrawal S. and Jameel S. (2000): The in vitro-synthesized RNA from a DNA clone of hepatitis E virus is infectious. J Virol 74: 2430-2437.

20. Ray R., Aggarwal R., Salunke P.N., Mehrotra N.N. Talwar G.P. and Naik S.R. (1991): Hepatitis E virus genomes in stools of hepatitis patients during large epidemic in north India Lancet 338: 783784.

21. Turkoglu S., Lazizi Y., Meng H Kordosi A. Dubreuit P., Grescenzo B., Benjelloun S., Nordmann P. and Pillot J. (1996): Detection hepatitis E virus RNA in stools and serum by reverse transcription polymerase chain reaction. J Clin Microbiol 34: 1568-1571. 


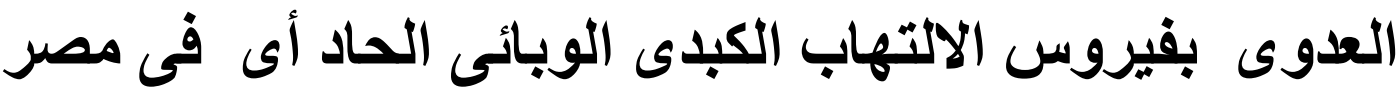

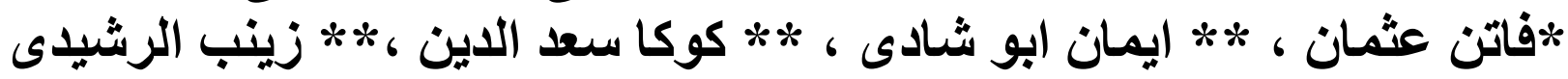

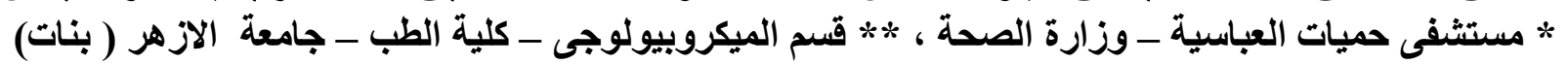

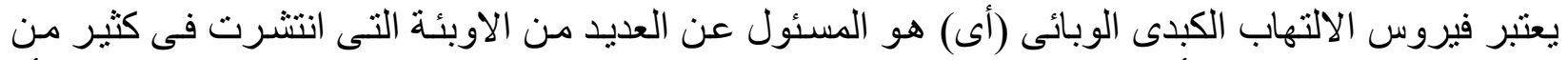

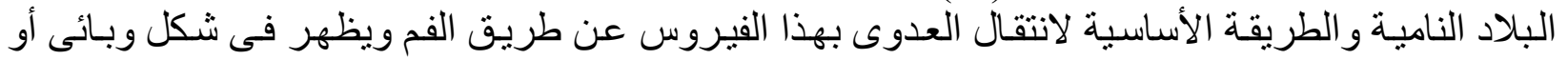

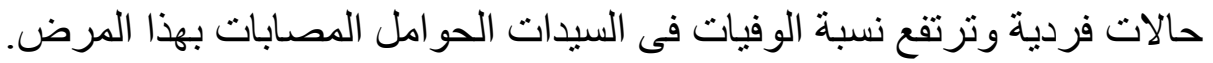

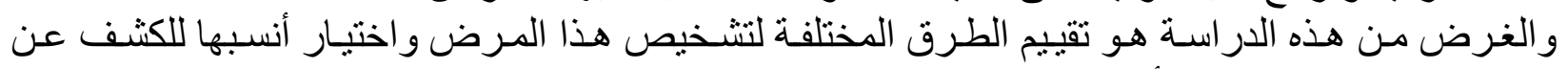

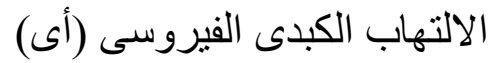

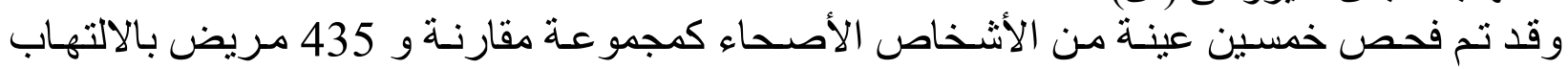

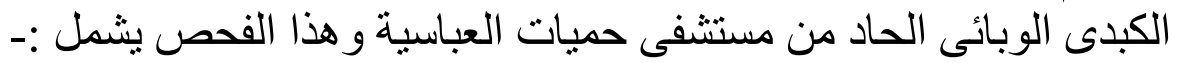
تحديد وظائف الكبد الكبدان

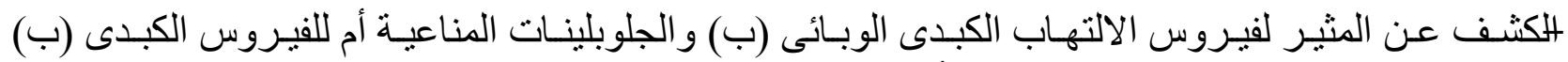

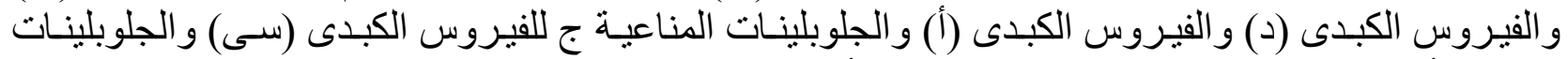

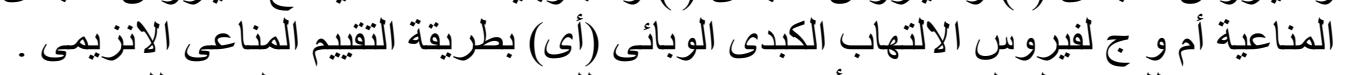

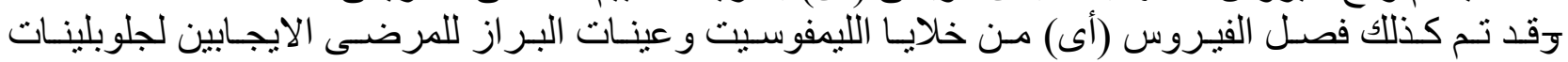

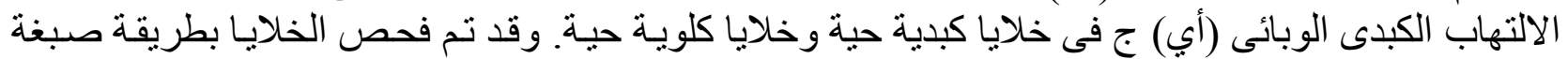

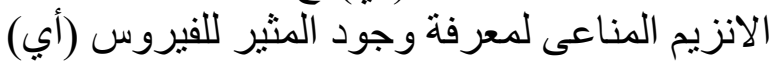
وتثم فحص عينات المصل وخلايا الليمفوسيت وعينات البراز لونيا لوجود الحمض النووى للفيروس بطريقة التفاعل

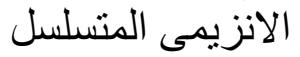

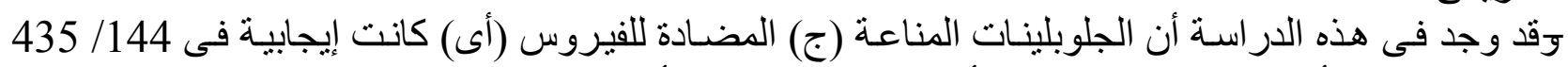

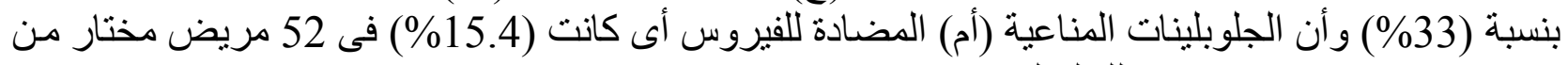

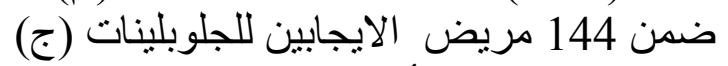

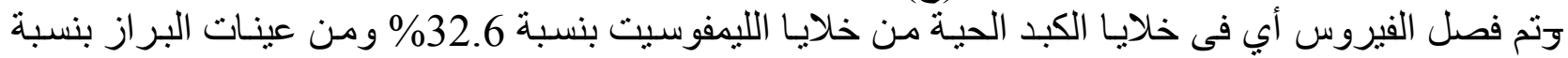

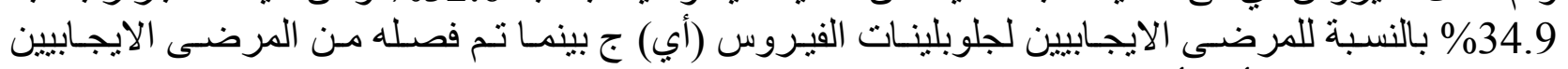

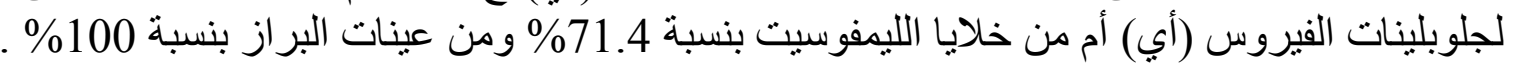

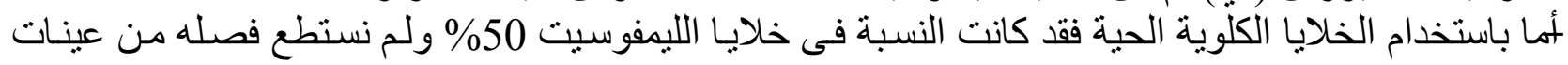
البراز

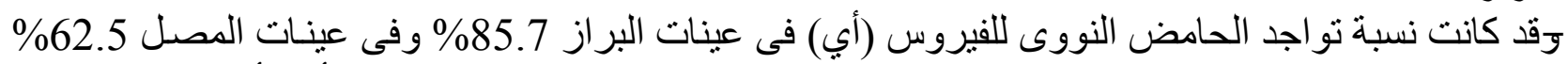

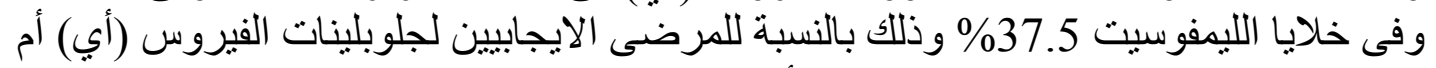

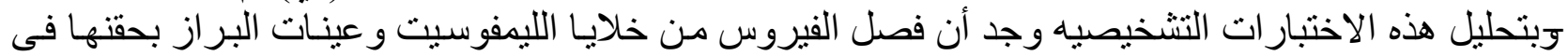

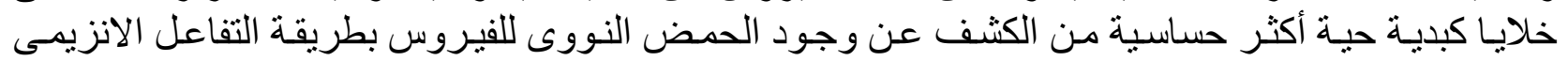

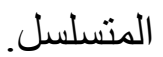

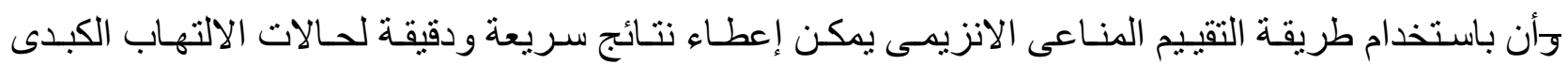

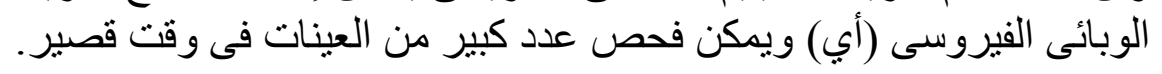

